\title{
Kombinasi Sistem Surjan-Handil sebagai Kecerdasan Lokal (Local Genius) dan Kearifan Lokal (Local Wisdom) Masyarakat Banjar Kuala di Kampung Tamban Mekar Sari Pal 16, Barito Kuala, Kalimantan Selatan
}

\author{
Rabini Sayyidati \\ Jurusan Teknik Informatika, Politeknik Negeri Tanah Laut \\ Email Penulis: rabini.sayyidati@gmail.com
}

\begin{abstract}
Abstrak
Komunitas pesisir yang dikenal sebagai orang Banjar Kuala memiliki kepedulian untuk melestarikan tata pengelolaan lahan pertanian. Pengelolaan lahan pertanian merupakan akses penting komunitas Banjar Kuala dalam pengelolaan sumberdaya alam. Oleh sebab itu, salah satu komunitas Banjar Kuala yang hingga sekarang tetap memelihara adat tata pengelolaan lahan pertanian adalah masyarakat Tamban Mekar Sari Pal 16, Kecamatan Tamban Mekar Sari, Kabupaten Barito Kuala, Kalimantan Selatan. Sistem nilai budaya sebagai bagian penting dari sistem sosial, dapat tercermin pada usaha masyarakat Tamban Mekar Sari Pal 16, melalui tata kelola lahan pertanian. Pengelolaan tanah berkaitan erat dengan sistem surjan. Sedangkan pengelolaan air berkaitan dengan sistem handil. Kedua sistem ini, pada zaman dahulu selalu diterapkan masyarakat Banjar Kuala umumnya, dan masyarakat Tamban Mekar Sari Pal 16 Barito Kuala khususnya, untuk mengelola sawah pada lahan rawa pasang surut. Melalui kombinasi sistem surjan-handil, ternyata memiliki hasil ganda. Satu sisi, pengairan sawah yang baik, akan menyuburkan tanaman padi, sekaligus meningkatkan produksi padi dan menambah pendapatan petani. Hasil berikutnya adalah tembokan, yang membentuk tukungan dan baluran, dapat ditanami palawija.
\end{abstract}

Kata kunci: Sistem, Surjan, Handil, Kecerdasan Lokal, Kearifan Lokal

\section{Abstract}

The coastal community known as the Banjar Kuala people have a concern to preserve the management of agricultural land. The management of agricultural land is an important access to the Banjar Kuala community in managing natural resources. Therefore, one of the Kuala Banjar communities which up to now maintains the custom of the management of agricultural land is the community of Tamban Mekar Sari Pal 16, Tamban Mekar Sari District, Barito Kuala District, South Kalimantan. The cultural value system as an important part of the social system, can be reflected in the efforts of the Tamban Mekar Sari Pal 16 community, through the management of agricultural land. Land management is closely related to the surjan system. While water management is related to the handil system. Both of these systems, in the past, were always applied by the Kuala Banjar community in general, and the community of Tamban Mekar Sari Pal 16 Barito Kuala in particular, to manage rice fields on tidal swamp land. Through a combination of the surjan-handil system, it turns out that it has double results. One side, good irrigation of rice fields, will fertilize rice plants, while increasing rice production and increasing farmers' income. The next result is the pot, which forms tukungan and baluran, can be planted with crop.

Keywords: System, Surjan, Handil, Local Genius, Local Wisdom 


\section{PENDAHULUAN}

Masyarakat Banjar, Kalimantan Selatan, terbagi atas tiga kelompok, yakni; Banjar Kuala, Banjar Batang Banyu, dan Banjar Hulu (Saleh, 1982). Pembagian ini berdasarkan geografis pemukiman, dan corak sosial budaya. Masyarakat Banjar Hulu mendiami kawasan Tanjung, Barabai, Kandangan dan Rantau. Banjar Batang Banyu mendiami kawasan Margasari dan Amuntai, sedangkan Banjar Kuala adalah masyarakat yang mendiami kawasan muara Sungai Barito, Barito Kuala, Banjarmasin dan Martapura (Tim, 1988). Berdasarkan topografis wilayahnya, masyarakat Banjar Hulu mendiami kawasan daratan dan pegunungan, masyarakat Banjar Batang Banyu mendiami kawasan aliran-aliran sungai (batang banyu), sedangkan masyarakat Banjar Kuala mendiami kawasan muara Sungai, yakni Muara Sungai Barito, Sungai Bahan dan Sungai Nagara (Ahmad dkk, 1980).

Pada kawasan muara Sungai Barito, Barito Kuala, terdapat perkampungan petani dan nelayan sungai, yang masuk dalam Kecamatan Tabunganen, Tamban Mekar Sari dan Kecamatan Tamban. Pekerjaan masyarakat dalam wilayah kecamatan bagian pesisir Kalimantan Selatan ini, pada umumnya menjadikan pekerjaan nelayan hanyalah sekedar pekerjaan sambilan, sedangkan pekerjaan pokoknya adalah bertani dan berkebun.

Komunitas pesisir yang dikenal sebagai orang Banjar Kuala memiliki kepedulian untuk melestarikan tata pengelolaan lahan pertanian. Pengelolaan lahan pertanian merupakan akses penting komunitas Banjar Kuala dalam pengelolaan sumberdaya alam. Oleh sebab itu, salah satu komunitas Banjar Kuala yang hingga sekarang tetap memelihara adat tata pengelolaan lahan pertanian adalah masyarakat Tamban Mekar Sari Pal 16, Kecamatan Tamban Mekar Sari, Kabupaten Barito Kuala, Kalimantan Selatan.

Masyarakat Tamban Mekar Sari Pal 16, merupakan masyarakat Banjar Kuala yang telah lama mendiami pemukiman aliran muara Sungai Barito. Aliran sungai Barito mengalir ke Sungai Tamban. Pada sekitar Sungai Tamban inilah secara adat turun temurun, masyarakat Tamban Mekar Sari Pal 16Barito Kuala melakukan pengelolaan lahan perkebunan kelapa dengan sistem surjan dan sistem handil.

Sistem surjan - handil merupakan adat tata pengelolaan lahan pertanian yang mengandung unsur kecerdasan lokal (local genius) dan kearifan lokal (local wisdom). Lewat sistem ini, masyarakat Tamban Mekar Sari Pal 16-Barito Kuala telah mencapai keberhasilan dalam berkebun kelapa, nenas, dan ubi kayu. Oleh sebab itu, makalah ini mencoba mengangkat bagaimana kecerdasan lokal dan kearifan lokal masyarakat Tamban Mekar Sari Pal 16, Barito Kuala, Kalimantan Selatan dalam tata pengelolaan lahan pertanian melalui sistem surjan-handil.

\section{METODE PENELITIAN}

Penelitian ini menggunakan metode penelitian kualitatif, yang mana mendeskripsikan tentang cara bertani masyarakat Tamban Mekar Sari menggunakan kombinasi sistem handil-surjan. Sistem ini sendiri mencerminkan kecerdasan serta kearifan lokal masyarakat setempat yang telah ada secara turun temurun.

Menurut Agus Salim (2001), penelitian kualitatif merupakan perangkat interpretatif terhadap fenomena sosial. Peneliti mengumpulkan data-data dan fakta yang ada dilapangan, kemudian menginterpretasikannya ke dalam tulisan. Melalui pendekatan kualitatif peneliti melakukan eskplorasi fenomena-fenomena yang tak bisa dikuantitaskan karena melihat gejala suatu budaya atau kebiasaan (Wahyu, 2012).

Selain itu menurut Nusa Putra (2013), bahwa penelitian kualitatif berdasarkan sudut pandang fenomenologi peneliti untuk sampai pada emik (paradigma/perspektif/perasaan) orang atau komunitas.

Metode kualitatif membantu untuk melihat dan menggambarkan fenomena yang ada pada objek penelitian kemudian dianalisis dengan pendekatan sosial yang tercermin pada masyarakat Tamban 
Sari Mekar Pal 16. Melalui metode kualitatif, kecerdasan dan kearifan lokal masyarakat yang menggunakan sistem surjan-handil dapat terdeskripsikan dengan baik.

Data yang diambil oleh penulis antara lain adalah mengenai letak geografis Desa Tamban Mekar Sari Pal 16, Kecamatan Tamban Mekar Sari, Kabupaten Barito Kuala. Kemudian mengenai keadaan sosial masyarakatnya yang berupa sistem perekonomian, cara bertani dan berkebun, dan tata kelola lahannya. Data didapat dengan melalukan observasi dan wawancara kepada masyarakat, selain itu juga melihat dokumen pembukuan hasil berdagang yang dimiliki oleh juragan-juragan perkebunan.

Setelah dilakukan verifikasi, data tersebut dianalisis dan disusun menjadi narasi yang menjelaskan bagaimana masyarakat Desa Tamban Mekar Sari mengelola lahan perkebunanannya dan membuat sistem sendiri yangmana merupakan sebuah bentuk adaptasi lingkungan berdasarkan hasil dari kecerdasan serta kearifan lokal yang sudah ada secara turun-temurun.

\section{HASIL DAN PEMBAHASAN}

\section{Sistem Surjan - Handil Sebagai Kecerdasan Lokal (Local Genius) dan Kearifan Lokal (Local Wisdom)}

Menurut J.L. Brandes, bangsa Indonesia memiliki kebudayaan asli, yang disebut sebagai "The Ten Point of Brandes". Salah satu point tersebut adalah sistem pertanian dan bercocok tanam (dalam Tundjung, 2010). Dalam konteks ini, sepanjang sejarah manusia selalu ada sekelompok masyarakat yang begitu peduli terhadap penggunaan sumberdaya alam yang berkelanjutan, dan kelompok tersebut telah mempraktekkan sistem konservasi sumberdaya alam dengan tepat (Gadgil dan Barkes, 1991 dalam Syafa'at, 2008)

Salah satu kecerdasan lokal yang patut dicermati adalah cara-cara masyarakat Tamban Mekar Sari Pal 16 Barito Kuala dalam menanam dan berkebun kelapa. Perkebunan kelapa masyarakat Tamban, paling dikenal di seluruh Kalimantan Selatan. Kampung Tamban umumnya, khususnya Tamban Mekar Sari Pal 16 sebagai sentral produksi kelapa di Kalimantan Selatan. Keberhasilan perkebunan kelapa di kampung ini, tidak terlepas dari penerapan tata kelola lahan pertanian yang lahir dari kecerdasan lokal dan kearifan lokal, yang diwarisi masyarakat Banjar Kuala, dalam mengelola tanah dan air untuk menopang kebutuhan hidup mereka sehari-hari. Dalam konteks ini, sistem surjan-handil termasuk pada sistem nilai budaya yang mengandung makna: a). Nilai budaya yang berorientasi ke masa depan, b) nilai budaya yang berhasrat untuk mengeksploitasi lingkungan dan kekuatan-kekuatan alam, c) nilai budaya yang beroreintasi menilai tinggi hasil karya manusia, dan d) nilai budaya yang menilai tinggi usaha orang yang dapat mencapai, sedapat mungkin atas usahanya sendiri (Usman, dkk, 1996/1997).

Sistem nilai budaya sebagai bagian penting dari sistem sosial, dapat tercermin pada usaha masyarakat Tamban Mekar Sari Pal 16, melalui tata kelola lahan pertanian. Pengelolaan tanah berkaitan erat dengan sistem surjan. Sedangkan pengelolaan air berkaitan dengan sistem handil. Kedua sistem ini, pada zaman dahulu selalu diterapkan masyarakat Banjar Kuala umumnya, dan masyarakat Tamban Mekar Sari Pal 16 Barito Kuala khususnya, untuk mengelola sawah pada lahan rawa pasang surut.

\section{Sistem Surjan - Handil: Kombinasi Tata Kelola Lahan dari Kecerdasan Lokal (Local Genius) dan Kearifan Lokal (Local Wisdom) Masyarakat Banjar Kuala}

Sistem surjan di Kalimantan Selatan dikenal sebagai Sistem Surjan Banjar. Sistem ini, lahir sebagai bentuk kecerdasan lokal dan kearifan lokal akibat kondisi lahan yang bersifat rawa pasang surut. Kondisi lahan rawa pasang-surut sangat menggantungkan pada sistem surjan yang sifatnya upaya untuk mengolah tanah, meninggikan tanah sesuai dengan aturan-aturan tata kelola tradisional yang telah dipahami oleh masyarakat Tamban Mekar Sari Pal 16-Barito Kuala.

Sistem surjan dilakukan petani Tamban Mekar Sari Pal 16-Barito Kuala dengan cara: melakukan penabukan (penggalian) pada tanah. Tanah lalu di tembok. Tembokan itu dibuat secara tukungan dengan sistem baluran, yakni memanjang seiring bidang tanah yang dimiliki petani. 
Tanah yang digali (ditabuk) lalu dibuat selokan memanjang, yang disebut parit (tabukan). Tanah galian dari parit, diangkat dan dijadikan tembok (timbukan), sehingga terbentuk baluran panjang, sesuai dengan panjang tanah. Pemilik tanah lainnya, boleh menyambung parit (tabukan) tersebut, dan meneruskan panjang tembokan tersebut.

Penerapan sistem surjan Banjar Kuala di Tamban, Barito Kuala pada lahan pertanian dan perkebunan pasang surut untuk menyediakan lahan tabukan yang tergenang, dan lahan tembokan, tukungan dan baluran yang kering. Oleh sebab itu, umumnya lahan tabukan dapat diusahakan untuk penanaman padi atau menggabungkannya dengan budi daya ikan (mina padi). Sedangkan lahan tembokan/tukungan/baluran untuk budidaya tanaman palawija, sayur-sayuran, buah-buahan, tanaman tahunan dan tanaman industri. Sistem surjan Banjar Kuala khususnya pada masyarakat Tamban, Barito Kuala, sebetulnya merupakan jawaban jenius masyarakat Banjar Kuala terhadap tantangan rawa pasang surut, yang sangat sulit diolah dan dikelola. Kesulitan pengelolaan lahan pasang surut, diantaranya: (a) tanaman akan selalu tergenang dan mati, jika dalam periodik air pasang 15 hari lebih, karena akar-akar tanaman palawija akan membusuk. (b) air yang bersifat payau, asam dan bertagar menyebabkan jenis tanaman produktif, seperti padi, akan mudah mati.

Galian sistem surjan menghasilkan parit (tabukan) yang berfungsi untuk mengalirkan air, yang berasal dari handil. Handi adalah tanah yang digali untuk menghubungkan parit-parit (tabukan) dengan sungai, sehingga air mengalir secara teratur di sela-sela antar tukungan dari surjan. Tata kelola air untuk persawahan dan perkebunan kelapa masyarakat Tamban-Barito Kuala secara tradisional ini dikenal dengan sistem handil.

Cara pembuatan sistem handil melalui; penggalian, dan pembuatan sungai kecil yang menghubungkan dengan sungai besar, yang mengalir melalui kampung Tamban-Barito Kuala. Sungai besar yang diberi nama Sungai Tamban ini, bermuara pada bagian Utara ke Sungai Barito, dan ujung sebelah selatan bermuara ke Kuala Lupak dan terus ke laut Jawa.

Untuk mengalirkan air dari Sungai Tamban diperlukan sebuah sistem yang disebut sistem handil. Handil berfungsi juga untuk transportasi menuju perkebunan dan persawahan. Transportasi yang biasa digunakan masyarakat Tamban adalah klotok (kapal kecil bermesin), dengan menggunakan bahan bakar bensin dan solar. Sebagian masyarakat Tamban lainnya, masih menggunakan perahu.

Handil yang telah mengalirkan air Sungai Tamban, kemudian mengalir pada parit-parit (tabukan) disisi kanan-kiri tukungan pada sistem surjan. Tanah digali (ditabuk) lalu dibuat selokan memanjang, yang disebut parit. Tanah galian dari parit, diangkat dan dijadikan tembok, sehingga terbentuk baluran panjang, sesuai dengan panjang tanah. Pemilik tanah lainnya, boleh menyambung oarit, dan meneruskan panjang tukungan tersebut.

Dengan kombinasi sistem surjan-handil, ternyata memiliki hasil ganda. Satu sisi, pengairan sawah yang baik, akan menyuburkan tanaman padi, sekaligus meningkatkan produksi padi dan menambah pendapatan petani. Hasil berikutnya adalah tembokan, yang membentuk tukungan dan baluran, dapat ditanami palawija, seperti; terung biru, karawila, timun, cabe merah, semangka, kacang panjang, dan lain-lain. Namun, bagi masyarakat Tamban, Barito Kuala, timbukan ditanami pohon kelapa. Antara pohon kelapa ditanami nenas dan ubi kayu. Kecerdasan lokal dan kearifan lokal masyarakat Tamban Mekar Sari Pal 16, melalui tradisi sistem surjan-handil merupakan hasil tradisi turun temurun, yang melihat potensi pasang surut sebagai media yang paling cocok untuk bertanam kelapa, padi, nenas dan ubi kayu.

\section{Sistem Surjan- Handil di Tamban Mekar Sari Pal 16, Barito Kuala: Sentral Kelapa, Nenas dan Ubi Kayu di Kalimantan Selatan}

Dalam menerapkan tata kelola lahannya, masyarakat Tamban Mekar Sari Pal 16 Barito Kuala menggunakan Handil sebagai faktor utama dalam mendukung sistem Surjan untuk penanaman pohon kelapa, nenas dan ubi kayu.

Kedalaman handil variatif, antara 2 sampai 3 meter. Lebar handil antara 1,5 sampai 3 meter. Sedangkan lebar galian parit, pada umumnya antara 0,5-1 meter. Kedalaman rata-rata 1 meter. Jika ditanami kelapa, maka jarak antara tembok sekitar 2-3 meter. Tinggi tembokanantara 0,75-1 meter. Sedangkan jarak tanam antar pohon kelapa, antara 2-3 meter. Diantara jarak pohon kelapa tersebut biasanya ditanami nenas dan ubi kayu. 
Fungsi tukungan (timbukan) dalam sistem Surjan ini sangat penting untuk menghadapi datangnya air pasang. Tukungan (timbukan) tidak akan tergenang air, karena telah tinggi dari permukaan rata-rata kebiasaan saat air pasang. Biasanya jarak antara air pasang dengan tinggi tukungan (timbukan) tersisa sekitar 0,40. Jika air lebih tinggi lagi, parit akan digali kembali, dan tanahnya ditimbunkan ke tukungan (timbukan) yang telah memadat, serta mengalami penurunan. Pada saat air pasang, biasanya buah kelapa yang telah dipetik, dilarutkan melalui parit (tabukan), dan sendirinya butir-butir biji kelapa akan tertampung di muara baluran parit yang langsung terhubung dengan Handil. Buah kelapa langsung dikumpulkan dan dimuat ke dalam klotok (perahu bermesin) atau ke dalam perahu. Dari Handil, buah kelapa dibawa ke muara handil yang terhubung dengan sungai Tamban, dan dari sini langsung dipasarkan ke Banjarmasin, termasuk ke Pasar Terapung muara Sungai Kuin di Sungai Barito.

Handil Pal 16, kampung Tamban Mekar Sari, berjumlah 8 buah, yakni; Handil Kalua, Sari Tani, Nasib Untung, Badak, Gaya Baru, Sekunder Pasar, Sekunder Kiri, dan Persada. Pada Handil Gaya Baru bermukim komunitas transmigran dari Tulungagung-Jawa Timur sekitar 24 KK. Mereka telah lama beradaptasi dengan sistem pertanian Surjan dan Handil. Mereka juga sangat terampil bertani di lahan rawa pasang surut. Hasil panen padi mereka mencapai 200-300 blik padi bersih pertahun.

Luas areal perkebunan kelapa masyarakat Tamban Mekar Sari Pal 16, Barito Kuala mencapai 560 hektar. Areal seluas ini, juga ditanami nenas, dan sebagian ubi kayu. Tanaman ubi kayu hanya sekitar 70 hektar.

Dengan sistem Surjan-Handil untuk perkebunan kelapa, ternyata hasilnya sangat menyejahterakan penduduk Tamban Mekar Sari Pal 16. Kampung Tamban Mekar Sari Pal 16, tercatat memiliki angka kesejahteraan yang tinggi, terbukti dengan, tingginya pendapatan pertahun, rata-rata perkapita antara 48 juta- 80 juta pertahun. Pendapatan ini berasal dari variasi usaha tani, seperti; gabungan bertanam padi, dengan berkebun; nenas, kelapa dan ubi kayu. Semua keberhasilan usaha ini, berkat penerapan local genius (kesecerdasan lokal) dan indigenous knowledge (kearifan lokal) melalui tradisi sistem surjan dan sistem handil. Pada musim kemarau, terkadang air menjadi asin, setidak-tidaknya mendekati asin (hanta). Meski kemarau, tetap saja proses pasang surut berlangsung. Namun, justru air asin dan hanta ini, sangat membantu bagi kesuburan dan keberhasilan tingkat produksi buah kelapa di daerah Tamban umumnya, dan kampung Tamban Mekar Sari Pal 16, khususnya.

Produksi satu hektar kebun kelapa di Tamban Mekar Sari Pal 16, menghasilkan 2.000 biji tiap bulan. Kisaran tahun 2018-2019 harga 1 biji kelapa Rp 1.400 di tingkat petani, sedangkan di pasar di Banjarmasin, seharga Rp 1.800 sampai Rp 2.000. Jika 2.000 biji kelapa dikalikan Rp 1.400 maka penghasilan petani kelapa di Tamban Mekar Sari Pal 16 dalam 1 bulan adalah Rp 2.800.000. Oleh sebab itu, secara ekonomi, masyarakat Tamban Mekar Sari Pal 16 tidak mengenal krisis ekonomi. Kalau harga minyak mahal, mereka mengolah sendiri, dengan menggunakan bahan dari kelapa.

Petani kelapa Tamban Mekar Sari Pal 16, juga memperoleh uang dari penjualan tempurung kelapa. Harga $1 \mathrm{~kg}$ tempurung kelapa Rp 250. Selain itu, sabut kelapa Tamban Mekar Sari Pal 16 tergolong bagus, dan dihargai Rp 250 per $\mathrm{kg}$. Bila saat senggang tiba, umumnya usai menanam padi dan usai panen padi, petani Tamban Mekar Sari Pal 16 membuat lidi dari lidi daun kelapa. Lidi dimanfaatkan oleh penjual sate untuk tusuk sate. Lidi juga dijadikan kakarik atau sapu. Harga sapu lidi sekitar Rp 1.000 .

Begitu banyak hasil daya produksi kelapa, semakin banyak pula sumber pendapatan petani. Salah seorang penduduk Tamban Mekar Sari Pal 16 yang berhasil mencapai taraf sejahtera melalui berkebun kelapa adalah Haji Jumri. Kebun kelapa H. Jumri tertata rapi di atas tukungan (timbukan) sistem surjan yang sangat baik. Diantara kebunnya mengalir air dari Sungai Tamban ke Handil Persada. Pohon kelapa miliknya, sangat subur dengan buah yang besar dan lebat. Rata-rata satu pohon sekitar 15-25 biji. H. Jumri setiap dua bulan dapat memetik 40.000 butir kelapa, dengan luas kebun 20 hektar. Pendapatan perbulan H. Jumri dari tanaman kelapa sekitar Rp 34.000.000. Saat ini Haji Jumri memiliki mobil Innova 2,7 G, mobil Mitsubishi Strada, dan Honda CR-V. Selain Haji Jumri, petani sukses lainnya adalah; Pambakal Suryani, H. Adul, dan H. Muriadi.

Selain tanaman kelapa yang ditanam dengan sistem surjan, petani Tamban Mekar Sari Pal 16, membudidayakan nenas. Tanaman nenas dibudidayakan di sela-sela pohon kelapa. Nenas TambanBarito Kuala terkenal dengan rasa manisnya karena dipetik saat buah sudah sangat tua, sebagian sudah 
masak. Jenis nenas yang dibudidayakan adalah; nenas paun, nenas madu dan nenas Bangka. Hasil satu kali panen nenas di Tamban Mekar Sari Pal 16 mencapai ratusan ton. Harga satu biji nenas Tamban ukuran sedang berkisar antara Rp 2000 - Rp 2.500. Harga ukuran besar antara Rp 4000 - Rp 5000. Rata-Rata petani menghasilkan nenas antara 1.000 biji sampai 4.000 biji dalam satu kali panen. Panen nenas antara 2 sampai 3 kali dalam setahun. Satu hektar kebun nenas menghasilkan antara 750 biji sampai 1.000 biji nenas. Jika rata-rata panen sekitar 750 biji x Rp 4.000 maka minimal sekali panen pendapatan petani dalam 1 hektar adalah Rp 3.000.000.

Jenis tanaman lainnya, yang dibudidayakan masyarakat Tamban-Barito Kuala adalah jenis ubi kayu crystal. Ubi kayu jenis ini sangat digemari masyarakat Banjar, karena jika digoreng terasa renyah dan empuk. Sangat bagus untuk membuat beragam jenis kue Banjar, seperti; gaguduh gumbili hinti, ulinulin, kakicak, putu mayang, kulak gumbili, kurkit dan lain-lain. Umbi dari ubi kayu crystal memiliki bongkah yang besar dan panjang, sehingga sangat bagus pula untuk membuat kripik singkong dan tela-tela. Harga $1 \mathrm{~kg}$ ubi kayu Rp 1.200. Rata-rata hasil 1 borongan $(17 \mathrm{x} 17 \mathrm{~m})$ mencapai $2.000 \mathrm{~kg}$. hasil yang didapat petani ubi kayu di Tamban Mekar Sari Pal 16-Barito Kuala sekitar Rp 1.400.000. Tiap 3 bulan sekali pucuk ubi kayu dijual dengan harga Rp 500 per-ikat besar. Satu kali petik dalam 3 bulan dalam 1 borongan (17x17 m) sekitar Rp 50.000 hingga Rp 75.000.

Keberhasilan pengelolaan sistem Surjan-Handil di kampung Tamban Mekar sari Pal 16 Barito Kuala tidak lepas pula dari masih kuatnya piranti tradisi setempat, yakni; ketokohan Tuan Guru (Ulama), Tatuha Masyarakat (Tokoh masyarakat), komunitas Jamaah Masjid dan Langgar (Surau), dan pendidikan Islam melalui pesantren. Piranti adat inilah yang menjadi anutan petani Banjar Kuala umumnya, dan petani kampung Tamban Mekar Sari, Barito Kuala khususnya (Noor, 2005).

\section{KESIMPULAN}

Masyarakat Tamban Mekar Sari Pal 16, berhasil memanfaatkan teknologi tata kelola lahan, dengan mengkombinasikan sistem surjan dan sistem handil. Sistem surjan dan handil adalah bentuk kecerdasan lokal dan kearifan lokal yang berakar dari tradisi turun temurun masyarakat Banjar Kuala.

Sistem surjan dan handil sangat cocok diterapkan untuk tata kelola lahan rawa pasang surut. Ternyata sistem ini juga telah diadaptasi dan dipergunakan oleh masyarakat transmigran dari Jawa, yang ditempatkan di Handil Gaya Baru Tamban Mekar Sari Pal 16, Barito Kuala. Komunitas ini juga berhasil dalam berkebun kelapa, padi, nenas dan ubi kayu.

Masyarakat Tamban Mekar Sari Pal 16, sebagai bagian dari komunitas Banjar Kuala telah membentuk sistem sosial-ekonominya, melalui kepandaian yang dimiliki nenek moyangnya sendiri. Kepandaian tersebut mampu mengangkat martabat komunitas Tamban Mekar Sari Pal 16 bersaing dalam produktivitas pertanian dan perkebunan, khususnya; kelapa, nenas dan ubi kayu. Nyiur Tamban, Kanas Tamban, dan Gumbili Tamban merupakan idiom yang telah melekat dan menjadi milik masyarakat Tamban.

\section{DAFTAR PUSTAKA}

Ahmad, Abdul Halim, dkk., (1980). Aspek Geografi Budaya dalam Wilayah Pembangunan Kalimantan Selatan. Departemen Pendidikan dan Kebudayaan Propinsi Kalimantan Selatan.

Ayatrohaedi. (1986). Kepribadian Budaya Bangsa (Local Genius). Pustaka Pelajar. Jakarta.

Nawawi , Ramli, dkk, (1994). Dampak Sosial Budaya Akibat Menyempitnya Lahan Pertanian Kelurahan Pelambuan Propinsi Kalimantan Selatan. Departemen Pendidikan dan Kebudayaan. Banjarmasin.

Noor, M. (2004). Lahan Rawa. Sifat dan Pengelolaan Tanah Bermasalah Sulfat Masam. PT. Raja Grafindo Persada. Jakarta

Noor, Yusliani. (2005). "Petani Banjar Kuala di Kalimantan Selatan, Sekilas Sejarah dan Budayanya", dalam Wiramatas, Jurnal Ilmu Sosial dan Ilmu Pendidikan, Jurusan Pendidikan IPS FKIP Unlam, Banjarmasin, Tahun I, Nomor 3, November.

Putra, Nusa. (2013). Penelitian Kualitatif IPS (Ilmu Pengetahuan Sosial). Bandung, Remaja Rosda Karya

Radam, Noer'id Haloei. (1997). “Asal-Usul Masyarakat dan Kebudayaan Banjar”. Makalah Seminar Kebudayaan dan Kesenian Daerah Banjar. Banjarmasin, Tanggal 11 Agustus 1997.

Rappana, Patta. (2016). Membumikan Kearifan Lokal dalam Kemandirian Ekonomi. CV Sah Media. Makassar. Ras, Johanes Jacobus. (Penerjemah Sitti Hawa Saleh). (2009). Hikayat Banjar. Departemen Kementerian Bahasa dan Pustaka Diraja Malaysia. 
Saleh, M. Idwar. (1983). Lukisan Perang Banjar 1859-1865. Museum Negeri Lambung Mangkurat. Banjarbaru Provinsi Kalimantan Selatan.

Salim, Agus. (2011). Teori Paradigma dan Penelitian Sosial. Tiara Wacana. Yogyakarta.

Syafaat, Rachmad. (2008). "Politik Hukum dan Hak-Hak Masyarakat Adat Terhadap Akses Sumber Daya Alam”, dalam Negara, Masyarakat dan Kearifan Lokal. In-Trans Publishing, Malang-Jawa Timur.

Tim. (1988). Daur Hidup Suku Banjar. Museum Negeri Lambung Mangkurat. Banjarbaru Provinsi Kalimantan selatan.

Tundjung. (2010). Materi Indonesia dan Dunia Dalam Sejarah Modern. Pascasarjana Pendidikan Ilmu Pengetahuan Sosial, FKIP UNLAM. Banjarmasin.

Usman, A. Gazali, dkk, (1995). Pembinaan Disiplin di Lingkungan Kotamadya Banjarmasin. Departemen Pendidikan dan Kebudayaan . Banjarmasin.

Usman, A. Gazali, dkk,. (1997). Integrasi Nasional Suatu Pendekatan Budaya Daerah Kalimantan Selatan. Departemen Pendidikan dan Kebudayaan. Banjarmasin.

Wahyu, (2012). Metodologi Penelitian Kualitatif. FKIP, Universitas Lambung Mangkurat. Banjarmasin.

\section{Biodata Penulis}

Rabini Sayyidati, Lahir di Banjarmasin, 5 Mei 1992. Penulis menempuh Sarjana S1 pada bidang Pendidikan Sejarah, dan S2 Pendidikan Ilmu Pengetahuan Sosial di Universitas Lambung Mangkurat, Kota Banjarmasin. Penulis mengajar di Politeknik Negeri Tanah Laut, dengan homebase di Jurusan Teknik Informatika. Mata kuliah yang diajarkan berupa Pancasila, Kewarganegaraan dan Karya Tulis Ilmiah. 